\title{
CO ŁĄCZY PRZYJACIÓŁ: RÓŻNICE CZY PODOBIEŃSTWA? BADANIE REPREZENTACJI WŁASNEGO JA I JA PRZYJACIELA WŚRÓD UKRAIŃSKICH KOBIET I MĘŻCZYZN
}

\begin{abstract}
STRESZCZENIE
Podstawą teoretyczną badania była koncepcja Ja Rogersa (1951, 1959, 1965, 1977). Badanie przeprowadzono z wykorzystaniem metody dyferencjału semantycznego autorstwa Osgooda (1957). Zadaniem osób badanych było zrekonstruowanie trzech Ja: 1) Ja realnego - prawdziwego obrazu siebie, czyli tego, jak badany widzi samego siebie i jak się czuje w rzeczywistości; 2) Ja idealnego, czyli tego, jakie cechy badany chciałby mieć, a ich w danym czasie nie posiada; oraz 3) Ja bliskiego przyjaciela, które może być odmienne od Ja realnego lub Ja idealnego osoby badanej albo do niego podobne. Odpowiedzi były analizowane pod kątem 3 czynników dyferencjału semantycznego: oceny, siły i aktywności, z wykorzystaniem testu $t$ Studenta. W badaniu udział wzięło 100 ukraińskich studentów (w tym 50 kobiet i 50 mężczyzn) Wydziału Ekologii i Technologii Chemicznej Donieckiego Narodowego Uniwersytetu Technicznego. Średnia wieku badanych osób wynosiła 21,56 $(S D=1,68)$. Wyniki badań pokazały, że odpowiedzi mężczyzn różnią się statystycznie istotnie $\mathrm{w}$ reprezentacjach własnego Ja realnego i Ja przyjaciela, ale w reprezentacjach własnego Ja idealnego i Ja przyjaciela nie różnią się. W odpowiedziach kobiet natomiast istotne różnice w reprezentacjach Ja idealnego i Ja przyjaciela występują pod kątem czynników siła i aktywność, a w reprezentacjach własnego Ja realnego i Ja przyjaciela różnią się statystycznie pod kątem czynnika ocena. Przeprowadzone badanie wykazało, że istnieją różnice w reprezentacjach własnego Ja oraz Ja przyjaciela u kobiet i mężczyzn w okresie wczesnej dorosłości.
\end{abstract}

Słowa kluczowe: przyjaźń jako fenomen społeczno-psychologiczny, czynniki powstania przyjaźni, różnice w reprezentacjach własnego Ja i Ja przyjaciela, różnice międzypłciowe przyjaźni

\section{WHAT CONNECTS FRIENDS: THE DIFFERENCES OR SIMILARITIES? \\ StUdy OF The RePResentation My Self and Self of My fRiend OF UKRAINIAN WOMEN AND MEN}

\section{ABSTRACT}

The study has revealed that there are differences in the representations of respondents Self and Self of his friend concerning men and women in early adulthood. The

1 Adres do korespondencji: daria.paniotova@amu.edu.pl. 
theoretical basis for the research was the concept of Self by Rogers (1951, 1959, 1965, 1977). According to this concept study was conducted using the method of Semantic Differential by Osgood (1957). This method assumes that in the process of diagnosis, the test consists of three images of Self: 1) Real Self, e.g. a true picture of yourself - how does person see herself and how does person feel, 2) Perfect Self or what features a respondent would like to have, which at the moment he does not have, and 3) The Self of his Friend, which allows respondent to emphasize its own characteristics that distinguish him from the other, or vice versa shows a similar picture of the Self of Friend to the image of his Real Self or Perfect Self. Responses were analysed using 3 factors: Rating, Strength, Activity. One hundred students from Ukraine took part in the research, including 50 women and 50 men from the Faculty of Ecology and Chemical Technology of Donetsk National Technical University. The average age of respondents was $M_{\text {age }}=21.56(S D=1.68)$. The results showed that the responses of men statistically significantly differ concerning representations of Real Self and Self of Friend, but do not differ concerning representations of the Perfect Self and Self of Friend. Furthermore responses of women statistically significantly differ concerning representations of the Perfect Self and Self of Friend but there are only two factors - Strength and Activity, and the representations of the Real Self and Self of Friend statistically significantly differ taking into account factor Rating.

Keywords: friendship as a socio-psychological phenomenon, factors of creation of friendship, differences in the representations My Self and Self of Friend, differences in friendship men and women

W obecnym świecie czujemy się coraz mniej bezpiecznie, np. w rodzinie czy w pracy. Istotnym źródłem szczęścia i poczucia bezpieczeństwa w tej sytuacji mogą być różne formy przyjaźni (Sztompka, 2008). Przyjaźń jest jedną z największych wartości społeczeństwa, jednym z najważniejszych typów relacji międzyludzkich, mających wpływ na proces tworzenia się ludzkiej osobowości (Cooper, 1980). Proces ten trwa przez całe życie i ulega zmianom wraz z rozwojem osobistym każdego człowieka.

Struktura osobowości, w której centrum znajduje się Ja, kształtuje się pod wpływem różnych czynników zewnętrznych i wewnętrznych, przeżywanych i doświadczanych przez daną osobę. Szczególnie ważne w tworzeniu Ja są kontakty ze znaczącymi innymi, które zasadniczo określają reprezentację jednostki (Burns, 1982; Hall, Lindzey, 1994; Rogers, 1961).

W ciągu naszego życia przeżywamy zmiany w relacjach osoba-otoczenie, które wpływają na kształtowanie własnego Ja (Brzezińska, 2005; Hall, Lindzey, 1994; Jakubowski, 1970; Rogers, 1961). Własne Ja można zdefiniować jako indywidualny dynamiczny system wyobrażeń jednostki o sobie i jej reprezentacji siebie, który kształtuje się i zmienia w ciągu życia i jest wynikiem samopoznania, samopostrzegania, samooceny i postrzegania jej przez inne osoby. Własne Ja może być realnym i idealnym, uporządkowanym i zdezintegrowanym. Ponadto w ramach Ja można wyróżnić treść pojęcia Ja, czyli samoocenę - wartościujące 
ustosunkowanie się jednostki do własnych cech, atrybutów i zdolności, oraz strukturę Ja, czyli sposób zorganizowania treści Ja (Campbell, Assanand, Di Paula, 2004; Juroszek, 2014). W tym miejscu warto też zaznaczyć, że zarówno struktura Ja ma istotny wpływ na jakość, długość, charakter i powstawanie najważniejszych relacji z otaczającym nas światem, jak i relacje mają wpływ na kształtowanie struktury Ja (McGinnis, 1991; Rogers, 1961). Jedną z tych relacji jest przyjaźń, która towarzyszy człowiekowi przez całe życie.

Jednak charakter i funkcje przyjaźni zmieniają się znacząco wraz z wiekiem. Przyjaźń dziecięca charakteryzuje się przywiązaniem emocjonalnym, zazwyczaj opartym na wspólnych działaniach. U nastolatków pojawia się identyfikacja siebie i własnego Ja oraz ujawnia się kwestia odnoszenia własnych doświadczeń do doświadczeń innych w celu dalszego samorozwoju. Stąd też intensywne poszukiwanie przyjaciół oraz częsta idealizacja przyjaźni. Z kolei w okresie wczesnej dorosłości - czasie najbardziej intensywnego i emocjonalnego komunikowania się z rówieśnikami - przyjaźń jest istotnym elementem egzystencji oraz społecznej adaptacji człowieka, a także czynnikiem rozwoju osobowości (Kulagina, 2001; Rogers, 1961).

Powstaje więc pytanie, jak rodzi się przyjaźń i w jaki sposób wybieramy sobie przyjaciół. Trzeba zaznaczyć, że ważnym aspektem tworzenia przyjaźni jest fakt, że ludzie nie wybierają sobie przyjaciół losowo (Zeggelink, 1995). Zgodnie z teorią wymiany (Altman, Taylor, 1973; Blau 1964; Homans, 1961; Stafford, 2015; Thibaut, Kelley, 1959) różnice w poszczególnych cechach między dwiema osobami mogą być same w sobie atrakcyjne i mogą stanowić podstawę do tworzenia bliskich relacji, zwłaszcza przyjaźni. Wybieramy sobie przyjaciół o cechach, których nie mamy, i w swoim przyjacielu odnajdujemy uzupełnienie własnych deficytów. Ważne jest, by być tego świadomym przy tworzeniu przyjacielskich stosunków, ponieważ niezgodność między wymyślonym obrazem przyjaciela i jego obrazem realnym może powodować trudności nie tylko w powstawaniu relacji przyjacielskich, lecz także relacjach międzyludzkich w ogóle.

\section{Przyjaźń jako fenomen społeczno-psychologiczny}

Nawiązania do przyjaźni można znaleźć już w traktatach filozoficznych starożytnych Greków i Rzymian (Baltzly, Eliopoulos, 2009). Do dziś jednak toczą się dyskusje na temat kształtu definicji przyjaźni - jest to jeden z najważniejszych problemów badawczych w obszarze badań nad przyjaźnią obok: znaczenia różnic płciowych oraz międzykulturowych dla nawiązywania i funkcjonowania przyjaźni, zmian przyjaźni w czasie, ewolucji przyjaźni i jej przyszłości (Szarota, 2014).

Można stwierdzić, że reprezentacja pojęciowa przyjaźni ma bogatą historię i zmieniała się wraz z upływem czasu oraz nastawaniem przemian kulturowych, a w chwili obecnej jest już traktowana zupełnie inaczej niż za czasów starożytnych czy w innych minionych epokach (Konstan, 1997). 
Aby mieć pełen obraz tego pojęcia, należy się cofnąć do źródeł pojęcia przyjaźni. W języku łacińskim pojawiają się określenia osoby, której możemy Z wzajemnością zaufać: amicus, czyli przyjaciel, i określenie samego zjawiska przyjaźni: amicitia (Kubicka, Suwała, 2013). Definicje i typologizacje przyjaźni, którymi posługiwali się starożytni Grecy i Rzymianie, pojawiają się w dziełach Platona, Ksenofonta, Arystotelesa i Cycerona (Grabińska, 2010).

Dla przykładu, według Arystotelesa przyjaźń jest relacją dwukierunkową wzajemnie powiązanych ze sobą osób ze względu na podobieństwo obyczajów, wzajemne rozdzielanie dóbr i wzajemną chęć czynienia dobra dla swojego przyjaciela (Andrzejuk, 2009).

Przyjaźń jest wartością przyjmującą kilka kształtów. Na podstawie tego Arystoteles wyróżnia zhierarchizowane typy przyjaźni:

1. Przyjaźń utylitarna - charakteryzuje się interesownością ze względu na pożytek.

2. Przyjaźń hedonistyczna - zawiera w sobie przyjemność oraz uczucie, dlatego jest doskonalszą formą przyjaźni niż przyjaźń utylitarna. W przyjaźni hedonistycznej czynnik emotywny dominuje nad intelektualnym.

3. Prawdziwa przyjaźń - najważniejsze jest w niej dobro drugiej osoby, wymaga czasu i poznania partnera. Prawdziwa przyjaźń występuje rzadko, ponieważ ludzie rzadko są doskonali moralnie (czyli działają zgodnie $\mathrm{z}$ wzorcem postępowania etycznego, a ich postawy są w pełni zgodne z prawami moralnymi) oraz dzielni etycznie (tzn. są ludźmi, którzy dobrze życzą swoim przyjaciołom, których przyjaźń jest trwała i bazuje na naturze przyjaciela, a nie na innych względach; Arystoteles, wyd. 2007; Grabińska, 2010).

W literaturze średniowiecza rzadko można spotkać nawiązania do przyjaźni, ponieważ relacje międzyludzkie opierały się wówczas głównie na fundamentach religijnych. Zjawisko przyjaźni zaczyna być opisywane ponownie w epoce renesansu i utrzymuje się to do czasów współczesnych (Wierzbicka, 2007; Znaniecki, 1965).

Od lat 80. XX w. zainteresowanie problematyką relacji przyjacielskich jest zauważalne w krajach Europy Wschodniej, zwłaszcza w Rosji i na Ukrainie, w pracach Kona (1980). Zwraca on uwagę na to, że w relacjach przyjacielskich nie występuje kwestia czerpania korzyści z drugiej osoby, a przyjaźń jest dobrem samym w sobie. Kon wskazuje również na to, że przyjaźń jest indywidualna, selektywna i opiera się na wzajemnej sympatii; przyjaźń - to relacja głęboka i intymna, wymaga nie tylko wzajemnej pomocy, lecz także wewnętrznej intymności, uczciwości i zaufania (Kon, 2005). Obecnie prace ukraińskich badaczy nad przyjaźnią mają charakter głównie przeglądowy i dotyczą kwestii teoretycznych, brak jest natomiast badań empirycznych (Bohonkova, 2014; Klimenko, 2010; Vasilevs'kij, 2010). W Polsce z kolei dotychczas przeprowadzono niewiele badań na temat zjawiska przyjaźni; koncentrują się one głównie na funkcjach, które przyjaźń pełni, 
np. badania wpływu przyjaźni na zdrowie osób starszych (Gutowska, 2011) oraz badania przyjaźni w kontekście wychowania człowieka (Andrzejuk, 2011).

\section{Kulturowy aspekt przyjaźni}

Ważnym aspektem we wszystkich badaniach nad przyjaźnią jest też aspekt kulturowy (Hofstede, G., Hofstede, G. J., 2007; Hofstede G. J., Minkov, Hofstede, G., 2016; Szarota, 2014). Wyniki przeprowadzonych dotychczas badań międzykulturowych sugerują, że przyjaźń nie ma formy uniwersalnej, lecz przyjmuje różne postacie w zależności od kontekstu kulturowego (Adams, Plaut, 2003).

Dla przykładu wyniki badań wymiarów kulturowych Hofstede (2011) pokazują, że Ukraina, mając wskaźnik indywidualizmu na poziomie 25 punktów, w porównaniu z Polską (wskaźnik 60) jest krajem bardziej kolektywistycznym (Polska jest więc krajem bardziej indywidualistycznym). W kulturach indywidualistycznych wartościami dominującymi są np. niezależność czy rozwój osobisty, punktem odniesienia zaś są w nich jednostka i jej dobro. W kulturach kolektywistycznych natomiast najważniejszymi wartościami są np. lojalność i współzależność, a punktem odniesienia, analogicznie, dobro grupy. Wymienione wartości znajdują swoje odbicie także w polsko-ukraińskich opisach przyjaźni. Przykładowo badanie językowego obrazu przyjaźni ukraińskich oraz polskich studentów pokazało, że dla Polaków ważne okazały się własny rozwój, zrozumienie, potrzeba odrębności i tolerancja dla odmienności. Dla studentów ukraińskich natomiast istotne były wzajemna pomoc, wsparcie i jakość więzi (Obrębska, Paniotova). Można założyć, że znacząca w tym kontekście jest niepewna sytuacja społeczno-polityczna, w której obecnie Ukraina się znajduje. Towarzyszy jej ciągłe poczucie zagrożenia obywateli w codziennym życiu, dlatego możliwość polegania na drugiej osobie i wzajemna pomoc stają się ważniejsze niż wspólne spędzanie wolnego czasu.

Z kolei badania w zakresie językoznawstwa porównawczego pokazują, że znaczenie przyjaciela i przyjaźni w większości języków jest ściśle związane z pojęciami pokrewieństwa, koleżeństwa (zwłaszcza relacji wojskowych) i miłości. Ogólnie prasłowiańskie słowo drugz etymologicznie znaczy 'przyjaciel', 'towarzysz' oraz 'inny', 'drugi', 'następny'. Starosłowiańskie drouzhba oznacza bliskość, partnerstwo, społeczeństwo. Rosyjski czasownik дружumь jest etymologicznie bliski serbochorwackiemu drużiti se - 'dołączać się', słoweński druziti - 'łączyć' itp. Warto zauważyć bliskość korzeni rodzinnych i wojskowych tych pojęć. W języku rosyjskim słowo drużyna oznacza jednostkę wojskową, w Słowenii i Bułgarii - rodzinę, a na Ukrainie - żonę (Wierzbicka, 2007).

Zwracając uwagę na etymologię pojęcia przyjaźni i przyjaciela w systemie anglosaskim, możemy zauważyć, że u podstaw wszystkich terminów (niemieckie freund, gotyckie frijonds, staroangielskie freond, staronordyckie fraend, starosaksońskie friund, staroniemieckie friunt, staroislandzkie fria) leży niemiecki 
korzeń „fri”, co znaczy 'chronić, 'dbać, albo angielski „fre” - freogan, freon, oznaczające 'kochać' (Wierzbicka, 2007).

Analizując etymologiczną spójność, można prześledzić pierwotną niepodzielność stosunków społecznych i osobistych oraz towarzyszących im emocji. W kontekście owej niepodzielności stosunków społecznych należy zwrócić uwagę, że reprezentacja pojęciowa przyjaźni ma charakter indywidualny i dlatego, jak zauważyli Winstead i Derlega (1986), badania powinny się koncentrować na definicji przyjaźni podawanej przez konkretne osoby oraz na tym, w jaki sposób własna koncepcja przyjaźni wpływa na rzeczywistość i otoczenie społeczne (Wierzbicka, 2007).

\section{Czynniki związane z wyborem przyjaciela i powstaniem przyjaźni}

Tworzenie, utrzymywanie i rozwiązywanie stosunków przyjacielskich jest uzależnione od wielu sprzężonych ze sobą czynników, które możemy określić jako indywidualne, relacyjne i środowiskowe, albo zewnętrzne (czynniki relacyjne i czynniki otaczającego nas środowiska), uznawane za główne przyczyny pojawienia się przyjaźni (Zeggelink, 1995) i wewnętrzne (indywidualne i osobiste cechy przedmiotu przyjaźni, np. charakteru czy temperamentu).

Do czynników zewnętrznych, które pozwalają przewidzieć, czy dwie osoby się zaprzyjaźnią, można zaliczyć bliskość terytorialną, a ściślej - odległość funkcjonalną, czyli częstotliwość przecinania się ścieżek dwóch osób. Często możemy znaleźć przyjaciół wśród osób, które korzystają z tego samego wejścia czy tego samego parkingu lub chodzą do tej samej siłowni. Te wzajemne kontakty sprzyjają definiowaniu siebie jako jednostki społecznej przez określenie gustów oraz zainteresowań, które łączą i dzielą dwie osoby mogące się stać przyjaciółmi. Darley i Berscheid (1967) zauważyli, że samo oczekiwanie spotkania już wzmacnia sympatię do osoby, z którą mamy się spotkać. Oczekiwanie zaś na przyjemne emocje, np. na to, że ktoś okaże się dla nas osobą miłą i przyjazną, zwiększa prawdopodobieństwo rozwoju dobrych stosunków między nami a tą osobą (1967).

Warto jednak zaznaczyć, że bliskość terytorialna stwarza dogodne warunki do powstania wzajemnej sympatii nie tylko dlatego, że ułatwia kontakty i sprzyja pozytywnym oczekiwaniom na nie, lecz także dlatego, że tworzy umiarkowaną szansę na pojawienie się osoby w polu naszego widzenia. Przeprowadzone na ten temat badania wykazały, że stymulacja (pojawienie się w polu widzenia) wywołuje pozytywne uczucia, nawet jeśli ludzie nie są świadomi faktu stymulacji. Ponadto nieświadoma percepcja bodźca daje jeszcze bardziej znaczący wpływ na formowanie sympatii (Kunst-Wilson, Zajonc, 1980; Moreland, Zajonc, 1977). Zajonc (1980) twierdzi, że emocje są szybsze oraz bardziej prymitywne niż myśli i dlatego efekt prostego pojawienia się w polu widzenia ma wielkie znaczenie adaptacyjne. Wyniki eksperymentów Zajonca i jego współpracowników (KunstWilson, Zajonc, 1980; Moreland, Zajonc, 1977) sugerują, że stymulacja i samo 
trafienie w pole widzenia wywołują pozytywne uczucia, nawet jeśli ludzie nie są świadomi faktu tej stymulacji. Jest to „mocno zmontowany” mechanizm ochronny, który pomagał naszym przodkom w klasyfikowaniu przedmiotów i ludzi, a także w przypisaniu ich do kategorii: znane i bezpieczne lub: nieznane i potencjalnie niebezpieczne.

Nowsze badania pokazują z kolei, że powstanie i dynamiczny rozwój mediów społecznościowych stanowi kolejny ważny czynnik dla powstawania przyjaźni, ponieważ wykreowały one nową, wirtualną przestrzeń spotykania przyjaciół i nowe sposoby nawiązywania relacji przyjacielskich, (Amichai-Hamburger, Kingsbury, Schneider, 2013; Ball, Newman, 2013).

Ważnym dla pojawienia się przyjaźni czynnikiem zewnętrznym jest także atrakcyjność fizyczna (Klimenko, 2010; Newcomb, 1956; Serdiuk, 2015; Vasilevs'kij, 2010). Badania nad nią wykazały istnienie zasady odpowiedniości i dowiodły, że mamy tendencję do wyboru przyjaciół spośród osób o podobnym do naszego poziomie atrakcyjności - zasadę tę obserwuje się także dla poziomu inteligencji (Feingold, 1988; Morry, 2007; Murstein, Azar, 1986). Osiągnięcie wysokiego poziomu odpowiedniości fizycznej stanowi zaś podstawę do bardziej harmonijnych oraz silnych relacji (White, 1980).

Zasada odpowiedniości znajduje także potwierdzenie w kolejnym czynniku zewnętrznym, którym jest status społeczny przyjaciół. Badania Dijkstry, Cillessena i Borcha (2013) wykazały, że młodzież zasadniczo woli wchodzić $\mathrm{w}$ relacje przyjacielskie $\mathrm{z}$ rówieśnikami o podobnym statusie społecznym.

Do czynników wewnętrznych można z kolei zaliczyć postawy, przekonania, wartości moralne, cechy charakteru (także negatywne, jak egoizm, narcyzm, skłonność do manipulacji), cechy temperamentu własnego Ja i Ja bliskiej dla nas osoby (Ilmarinen, Lönnqvist, Paunonen 2016; Maaß, Lämmle, Bensch, Ziegler, 2016). Wielu badaczy podejmowało kwestię podobieństwa, starając się odpowiedzieć na pytanie: „Czy podobieństwo rodzi sympatię, czy sympatia rodzi podobieństwo?" (Byrne, 1961; Hensley, 1994; Klohnen, Luo, 2003; McCroskey, McCain, 1974; Schug, Yuki, Horikawa, Takemura, 2009). W swoich eksperymentach doszli oni do wspólnego wniosku, że to podobieństwo rodzi sympatię, a nie odwrotnie. Wyniki pokazały bowiem, że im więcej badani mieli podobieństw w poglądach, zainteresowaniach, postawach i wartościach, tym większa była szansa, że takie osoby będą przyjaciółmi oraz że ich związki będą trwałe i mocne.

Choć czynnik podobieństwa jest dla pojawienia się przyjaźni bardzo istotny, funkcjonuje również pogląd, że równie istotne mogą się okazać przeciwieństwa - zasada „przeciwieństwa się przyciągają” (Dryer, Horowitz, 1997; Kristof-Brown, Barrick, Stevens, 2005). Wyniki eksperymentu Dryera i Horowitza (1997) dowodzą, że osoby nawzajem się uzupełniające (np. uległe z dominującymi lub dominujące z uległymi) odnoszą większą satysfakcję ze związku niż osoby w relacjach, w których partnerzy są do siebie podobni. Dlatego to, czy w danej relacji przyjacielskiej istotniejsze okażą się podobieństwa czy przeciwieństwa, 
zależy od sposobu postrzegania siebie oraz innych, w którym to postrzeganiu główną rolę odgrywa Ja, a także od różnic płciowych (np. dziewczynki holenderskie dobierają sobie przyjaciół, bazując na zasadzie podobieństwa w większej mierze niż chłopcy; Selfhout, Branje, Meeus, 2007) czy kulturowych (np. poziom podobieństwa między przyjaciółmi w krajach zachodnich jest większy niż w krajach Azji Wschodniej; Schug, Yuki, Horikawa, Takemura, 2009).

\section{Rola postrzegania własnego Ja i Ja bliskiej osoby $\mathrm{w}$ relacjach przyjacielskich} Obraz Ja zajmuje centralne miejsce w strukturze naszej osobowości i ma bezpośredni wpływ na nasze zachowanie, procesy poznawcze, psychiczne i emocjonalne (Suszek, 2007). Sciangula i Morry (2009) w swoich badaniach dotyczących bliskich, intymnych relacji pokazali, w jaki sposób reprezentacja własnego Ja ma wpływ na jednostkowe samopostrzeganie i poglądy o tym, jak będziemy postrzegani przez swoich partnerów (metaperception). Badania te dowiodły m.in., że dla umiarkowanych związków (moderate relationship), które autorzy definiują jako związki charakteryzujące się takimi cechami jak opiekuńczość i kochanie (w sumie wyróżnili dla nich 20 cech istotnych statystycznie), wysoka samoocena była związania z samodowartościowywaniem (typem motywacji, który powoduje, że dana osoba myśli dobrze o sobie samej, idealizuje się), podczas gdy niska samoocena była związana z samodezaprobatą (typem motywacji, który powoduje, że dana osoba myśli o sobie samej źle). Znaczy to, że osoby $\mathrm{z}$ wysoką samooceną będące $\mathrm{w}$ związkach umiarkowanych starały się samodowartościowywać, co miało bezpośredni wpływ na ich satysfakcję ze związku (np. wiedzieli, że umieją rewelacyjnie gotować i zawsze starali się to pokazywać). Osoby z niską samooceną nie charakteryzowały się natomiast samodowartościowaniem i miały pośredni wpływ na jakość związku - popierały swojego partnera w tym, co robi, i cieszyły się z jego sukcesów (Sciangula, Morry, 2009).

Podobnie wygląda to w relacjach przyjacielskich. Jakość relacji i satysfakcja zależą od tego, jak postrzegamy własne Ja i Ja przyjaciela, oraz od tego, jak ta ocena odpowiada rzeczywistości. Ja przyjaciela to postrzeganie, proces oceny i konstrukcji obrazu przyjaciela przez jednostkę. W procesie samorealizacji człowieka bowiem bardzo ważne jest zaspokojenie potrzeby pozytywnej oceny, zarówno ze strony innych osób, jak i samego siebie. Potrzeba pozytywnej oceny ze strony innych ludzi powoduje, że osoba jest narażona na wpływ społecznej akceptacji lub dezaprobaty. Potrzeba pozytywnego postrzegania samego siebie jest zaspokojona, jeżeli człowiek uznaje swoje doświadczenie i zachowanie za zgodne z koncepcją własnego Ja.

Na tej podstawie można więc stwierdzić, że istotne jest zbadanie, czy widzimy przyjaciela jako podobnego do nas czy też odmiennego. Celem niniejszej pracy jest udzielenie odpowiedzi na pytanie: Jak kształtują się różnice w reprezentacjach własnego Ja (realnego i idealnego) i Ja przyjaciela wśród kobiet i mężczyzn 
w wieku wczesnej dorosłości? W hipotezie badawczej założono, iż kobiety i mężczyźni różnią się w reprezentacjach własnego Ja realnego oraz Ja idealnego pod względem reprezentacji Ja przyjaciela.

\section{Wykorzystana koncepcja teoretyczna: Ja Rogersa}

Teorią, która została zaaplikowana w kontekście realizacji postawionego celu badawczego oraz weryfikacji hipotezy badawczej, jest koncepcja Ja Rogersa $(1951,1959,1961,1965,1977)$. Autor wychodzi w niej bowiem od założenia, że reprezentacja własnego Ja jednostki powstaje w procesie socjalizacji, w który zaangażowani są istotni inni, np. rodzice, rodzeństwo czy właśnie przyjaciele. W procesie tej socjalizacji formuje się struktura Ja, która według Rogersa składa się z dwóch elementów - Ja realnego i Ja idealnego. Treść Ja realnego odpowiada głównie na pytanie ,jakim jestem?”, a tworzą ją samoocena i postawa jednostki wobec siebie w czasie rzeczywistym. Z kolei treść Ja idealnego odpowiada na pytanie ,jakim chciałbym być?” i zawiera w sobie cechy, których w naszej własnej opinii nie mamy, ale które chcemy mieć w przyszłości. Niniejsze badanie dotyczy właśnie istotnych innych - przyjaciół i pokazuje, w jaki sposób osoby badane reprezentują własne Ja względem Ja swojego przyjaciela. Dostarcza ono odpowiedzi na pytanie, czy osoby badane utożsamiają swoich przyjaciół z własnym Ja realnym czy też z Ja idealnym (Jakubowski, 1970; Rogers, 1951, 1959, 1961, 1965, 1977).

\section{MetodA}

\section{Osoby badane}

W badaniu udział wzięło 100 studentów z Ukrainy, w tym 50 kobiet i 50 mężczyzn, z Wydziału Ekologii i Technologii Chemicznej Narodowego Uniwersytetu Technicznego w Doniecku. Średnia wieku badanych osób wynosiła 21,56 $(S D=1,68)$.

\section{Procedura badawcza}

Badanie przeprowadzono w grupach. Uczestnicy zostali poinformowani o celu przeprowadzenia badania, jakim było uzyskanie informacji na temat reprezentacji własnego Ja i Ja przyjaciela kobiet i mężczyzn w wieku wczesnej dorosłości. Respondenci otrzymali informację o dobrowolnym udziale w badaniu, o anonimowości badania, czasie jego trwania, sposobie przeprowadzenia i prawie do przerwania udziału w badaniu w każdym momencie, bez konieczności podawania przyczyny.

\section{Narzędzie badawcze}

W badaniu własnym wykorzystano metodę dyferencjału semantycznego (Charles E. Osgood's Semantic Differential; DS). Tekst metody został zaadaptowany na język 
rosyjski w 1983 roku w Instytucie Neuropsychiatrycznym im. V. M. Behtereva w Petersburgu (Fetiskin, Kozlov, Manujlov, 2002; Osgood, 1957). Narzędzie to pozwala na zbadanie obrazu własnego Ja realnego, Ja idealnego oraz Ja przyjaciela, z uwzględnieniem indywidualnego postrzegania własnej wartości, poziomu roszczeń, samoregulacji woli i rozwoju umiejętności komunikacyjnych w relacjach międzyludzkich. Dyferencjał semantyczny oparty na samoocenie stanu funkcjonalnego jednostki pozwala na przeniesienie otrzymanej obiektywnej informacji na język subiektywnie urefleksyjnianych cech osobowości (Osgood, 1957).

Metoda polega na wyborze spośród 42 przymiotników (antonimów) oznaczających cechy osobowości (np. dobry-zły, aktywny-pasywny, silny-słaby, atrakcyjny-nieatrakcyjny itd.). Przymiotniki zajmują skrajne pozycje na skali składającej się z siedmiu ocen (od -3 do +3 ). Według tej skali badana osoba ocenia przymiotnik najbardziej odpowiadający jej osobowości. Każdy przymiotnik odnosi się do jednego z trzech klasycznych czynników DS: ocena (wartościowanie), siła i aktywność.

Czynnik ocena charakteryzuje poziom poczucia własnej wartości, akceptacji siebie i swojej osobowości, rozpoznanie u siebie uznanych społecznie cech, krytyczny stosunek do samego siebie, zadowolenie z siebie. Czynnik oceny zawiera następujące antonimy: nieodpowiedzialny-pilny, altruistyczny-egoistyczny, nieczuły-czuły, sprawiedliwy-niesprawiedliwy, wrogi-przyjazny, uczciwy-fałszywy. Wysoka wartość tego czynnika wskazuje na akceptację samego siebie, niska - na stosunek krytyczny.

Czynnik siła charakteryzuje poziom pewności siebie i skłonność do polegania na swojej sile $w$ trudnych sytuacjach i zawiera następujące antonimy: słaby-silny, uparty-uległy, zależny-niezależny, zdecydowany-niezdecydowany, rozluźniony-zestresowany, pewny-niepewny, niesamodzielny-samodzielny. Jego wysoka wartość świadczy o pewności siebie, niska - o jej braku.

Czynnik aktywność charakteryzuje takie cechy jak komunikatywność, aktywność, energiczność, emocjonalne reagowanie na sytuację i impulsywność i zawiera następujące antonimy: rozmowny-milczący, zamknięty-otwarty, aktywny-pasywny, niemrawy-energiczny, niespokojny-spokojny, nietowarzyski-towarzyski, nerwowy-niewzruszony. Wysoka wartość czynnika wskazuje na ekstrawersję, niska - na introwersję.

Odpowiedzi badanych odnośnie do tych trzech czynników były analizowane $\mathrm{z}$ wykorzystaniem testu $t$ Studenta (porównanie średnich dwóch niezależnych prób). Porównania wśród kobiet i mężczyzn dotyczyły: 1) własnego Ja realnego własnego Ja idealnego, 2) własnego Ja realnego - Ja przyjaciela, 3) własnego Ja idealnego - Ja przyjaciela.

Należy jednak wziąć pod uwagę, że wyniki badań przeprowadzonych z wykorzystaniem metody dyferencjału semantycznego odzwierciedlają subiektywne, emocjonalne i semantyczne reprezentacje osoby i innych ludzi i mogą tylko 
częściowo odzwierciedlać rzeczywisty stan rzeczy (Fetiskin, Kozlov, Manujlov, 2002).

\section{WYNIKI}

Wyniki przeprowadzonego badania pokazały, że istnieją statystycznie istotne różnice w reprezentacji własnego Ja i Ja przyjaciela u kobiet i mężczyzn. Analizę porównań własnego Ja realnego i Ja idealnego wśród mężczyzn i kobiet przedstawia tabela 1.

Tabela 1

Wyniki analizy średniej testem $t$ Studenta $w$ porównywaniu własnego Ja realnego i Ja idealnego wśród mężczyzn i kobiet

\begin{tabular}{lccccccc}
\hline \multirow{2}{*}{ Czynniki DS } & \multicolumn{2}{c}{$\begin{array}{c}\text { Własne Ja } \\
\text { realne }\end{array}$} & \multicolumn{2}{c}{$\begin{array}{c}\text { Własne Ja } \\
\text { idealne }\end{array}$} & \multirow{2}{*}{$t(98)$} & $d$ & $p$ \\
\cline { 2 - 5 } \multicolumn{1}{c}{} & \multicolumn{1}{c}{$S D$} & $M$ & $S D$ & & & \\
\cline { 1 - 5 } Mężczyźni & & & & & & & \\
ocena & 11,72 & 4,58 & 14,72 & 4,99 & 3,14 & 0,63 & $0,002^{* *}$ \\
siła & 7,96 & 3,79 & 9,88 & 5,00 & 2,16 & 0,43 & $0,033^{*}$ \\
aktywność & 5,04 & 3,56 & 7,48 & 3,89 & 3,27 & 0,65 & $0,001^{* * *}$ \\
Kobiety & & & & & & & \\
ocena & 13,12 & 4,33 & 15,64 & 2,98 & 3,39 & 0,68 & $0,001^{* * *}$ \\
siła & 9,88 & 4,18 & 12,16 & 3,79 & 2,85 & 0,57 & $0,005^{* *}$ \\
aktywność & 7,04 & 3,92 & 9,80 & 2,72 & 4,09 & 0,82 & $0,001^{* * *}$ \\
\hline
\end{tabular}

${ }^{*} p<0,05 ;{ }^{* *} p<0,01 ; * * *<0,001$.

Analiza testem $t$ Studenta dla prób niezależnych wykazała, że u mężczyzn występują statystycznie znaczące różnice między Ja realnym oraz Ja idealnym pod względem wszystkich trzech czynników: oceny, siły i aktywności. Porównywanie Ja realnego oraz Ja idealnego kobiet $\mathrm{z}$ wykorzystaniem testu $t$ Studenta wykazało również statystycznie istotne różnice pod względem wszystkich trzech czynników: oceny, siły i aktywności.

W porównywaniu własnego Ja realnego i Ja przyjaciela mężczyzn znaleziono istotne różnice pod względem wszystkich trzech czynników: oceny, siły i aktywności. Wyniki porównań przedstawia tabela 2. Średnia otrzymanych wyników dla własnego Ja realnego mężczyzn jest istotnie niższa od średniej ocen Ja przyjaciela. Własne Ja realne kobiet i Ja przyjaciela różni się natomiast istotnie tylko pod względem czynnika ocena. Średnia otrzymanych ocen Ja realnego kobiet pod względem czynnika ocena jest istotnie niższa od średniej Ja przyjaciela. 
Tabela 2

Wyniki analizy średniej testem $t$ Studenta $w$ porównywaniu własnego Ja realnego i Ja przyjaciela wśród mężczyzn i kobiet

\begin{tabular}{|c|c|c|c|c|c|c|c|}
\hline \multirow{2}{*}{$\begin{array}{l}\text { Czynniki } \\
\text { DS }\end{array}$} & \multicolumn{2}{|c|}{$\begin{array}{l}\text { Własne Ja } \\
\text { realne }\end{array}$} & \multicolumn{2}{|c|}{$\begin{array}{l}\text { Własne Ja } \\
\text { przyjaciela }\end{array}$} & \multirow[t]{2}{*}{$t(98)$} & \multirow[t]{2}{*}{$d$} & \multirow[t]{2}{*}{$p$} \\
\hline & $M$ & $S D$ & $M$ & $S D$ & & & \\
\hline \multicolumn{8}{|l|}{ Mężczyźni } \\
\hline ocena & $\begin{array}{r}11,72 \\
70\end{array}$ & 4,58 & 15,92 & 3,52 & 5,14 & 0,98 & $0,001 * * *$ \\
\hline siła & 7,96 & 3,79 & 11,20 & 4,84 & 3,73 & 0,74 & $0,001^{* * *}$ \\
\hline aktywność & 5,04 & 3,56 & 8,36 & 6,20 & 3,28 & 0,66 & $0,001 * * *$ \\
\hline ocena & 13,12 & 4,33 & 16,64 & 2,60 & 4,93 & 0,95 & $0,001 * * *$ \\
\hline siła & 9,88 & 4,18 & 9,24 & 6,27 & 0,60 & 0,12 & 0,550 \\
\hline aktywność & 7,04 & 3,92 & 8,40 & 3,94 & 1,73 & 0,35 & 0,087 \\
\hline
\end{tabular}

$* * * p<0,001$

W tabeli 3 znajdują się wyniki porównań własnego Ja idealnego i Ja przyjaciela wśród mężczyzn i kobiet. W porównywaniu średnich własnego Ja idealnego i Ja przyjaciela mężczyzn pod względem wszystkich trzech czynników: oceny, siły i aktywności nie znaleziono istotnych różnic.

U kobiet natomiast w porównywaniu własnego Ja idealnego i Ja przyjaciela znaleziono statystycznie istotne różnice pod względem czynników siła i aktywność. Średnia otrzymanych wyników dla własnego Ja idealnego kobiet pod względem czynników siła i aktywność jest istotnie wyższa od średniej ocen Ja przyjaciela kobiet. Pod względem czynnika ocena nie zaleziono istotnych różnic.

Tabela 3

Wyniki analizy średniej testem $t$ Studenta w porównywaniu własnego Ja idealnego i Ja przyjaciela wśród mężczyzn i kobiet

\begin{tabular}{|c|c|c|c|c|c|c|c|}
\hline \multirow{2}{*}{$\begin{array}{l}\text { Czynniki } \\
\text { DS }\end{array}$} & \multicolumn{2}{|c|}{$\begin{array}{c}\text { Własne Ja } \\
\text { idealne }\end{array}$} & \multicolumn{2}{|c|}{$\begin{array}{l}\text { Własne Ja } \\
\text { przyjaciela }\end{array}$} & \multirow[t]{2}{*}{$t(98)$} & \multirow[t]{2}{*}{$d$} & \multirow[t]{2}{*}{$p$} \\
\hline & $M$ & $S D$ & $M$ & $S D$ & & & \\
\hline \multicolumn{8}{|l|}{ Mężczyźni } \\
\hline ocena & 14,72 & 4,68 & 15,92 & 3,52 & 1,39 & 0,29 & 0,168 \\
\hline siła & 9,88 & 5,00 & 11,20 & 4,84 & 1,34 & 0,27 & 0,183 \\
\hline $\begin{array}{l}\text { aktywność } \\
\text { Kobiety }\end{array}$ & 7,48 & 3,89 & 8,36 & 6,20 & 0,85 & 0,17 & 0,398 \\
\hline ocena & 15,64 & 2,98 & 16,64 & 2,60 & 1,79 & 0,36 & 0,077 \\
\hline siła & 12,16 & 3,79 & 9,24 & 6,27 & 1,82 & 0,56 & $0,006 * *$ \\
\hline aktywność & 9,80 & 2,73 & 8,40 & 3,94 & 2,07 & 0,41 & $0,041^{*}$ \\
\hline
\end{tabular}

${ }^{\star} p<0,05 ;{ }^{* *} p<0,01$. 


\section{DYSKUSJA}

Otrzymane wyniki dowodzą, że istnieją rozbieżności w reprezentacjach własnego Ja realnego, Ja idealnego oraz Ja przyjaciela u kobiet i mężczyzn i tym samym pozytywnie weryfikują postawioną $\mathrm{w}$ badaniu hipotezę.

Zarówno kobiety, jak i mężczyźni reprezentowali własne Ja realne jako mniej pozytywne niż własne Ja idealne pod względem wszystkich trzech czynników: oceny, siły i aktywności. Różnice te potwierdzają obliczone wielkości efektu $d$ Cohena, które przyjmowały wartości w przedziale od 0,43 do 0,82. Charakteryzując własne Ja realne, badani rzadziej wybierali takie cechy, jak: odpowiedzialność, altruizm, uczciwość, aktywność, rozmowność, energiczność, towarzyskość, siła, niezależność, zdecydowanie, rozluźnienie, pewność, samodzielność, częściej przypisując te cechy własnemu Ja idealnemu. To dążenie do ideału jest właściwe dla wieku wczesnej dorosłości, jak również dla pragnienia rozwoju, samodzielności, wyrażania siebie (Rogers, 1961).

Jeśli chodzi zaś o reprezentacje Ja przyjaciela w stosunku do własnego Ja realnego oraz własnego Ja idealnego wśród mężczyzn, to istotne różnice pod względem wszystkich trzech czynników: oceny, siły i aktywności wystąpiły między reprezentacjami Ja przyjaciela i własnego Ja realnego, wielkość efektu $d$ Cohena przyjmowała wartości mieszczące się w przedziale od 0,66 do 0,98 . Z kolei między reprezentacjami Ja przyjaciela i własnego Ja idealnego różnice nie wystąpiły; potwierdzają to małe wielkości efektu $d$ Cohena, mieszczące się w przedziale od 0,17 do 0,29. Mężczyźni przypisywali bowiem Ja przyjaciela cechy bardziej pozytywne niż własnemu Ja realnemu, np. ujmujący, silny, rozmowny, pilny, otwarty, uczciwy, altruistyczny.

Z kolei reprezentacje Ja przyjaciela w stosunku do własnego Ja realnego oraz własnego Ja idealnego wśród kobiet pokazały, że własne Ja realne kobiet różniło się od Ja przyjaciela pod względem czynnika ocena $(d$ Cohena $=0,95)$, własne Ja idealne kobiet różniło się zaś od Ja przyjaciela pod względem czynników siła i aktywność; potwierdzają to średnie wartości wielkości efektu. Znaczy to, że kobiety nie reprezentują swoich przyjaciół jako osób silniejszych, aktywniejszych, pewniejszych, bardziej niezależnych, zdecydowanych, rozluźnionych i samodzielnych niż one same, ale jako osoby bardziej ujmujące, pilne, altruistyczne, czułe, sprawiedliwe, uczciwe. Kobiety w przyjacielu szukają więc akceptacji i wzmocnienia poczucia własnej wartości oraz wzmocnienia swojej osobowości.

Odnalezione różnice pokazują, że reprezentując własne Ja i Ja przyjaciela, zarówno kobiety, jak i mężczyźni wybierają przyjaciół spośród osób, które mają cechy odmienne od nich, uzupełniając tym samym brak tych cech u siebie. Potwierdza to założenia przyjęte w teoriach osobowości Murraya (1938) i Rogersa (1951) oraz badaniach późniejszych (Dryer, Horowitz, 1997; Plusnin, 1993; Reilly, Commins, Stefic, 1960; Rodina, 2000; Winch, Ktsanes, T., Ktsanes, V., 1955), że przyjaźń jest relacją komplementarną, która sugeruje wzajemne zaspokajanie potrzeb między dwiema osobami. Należy jednak podkreślić, że odmienności 
w konkretnych cechach poszukiwane są na zasadzie komplementarności w odniesieniu do cech, które w najmniejszym stopniu zależą od wychowania i socjalizacji (np. introwersja-ekstrawersja). Nie stoi to więc w sprzeczności z faktem, że w kształtowaniu przyjaźni między osobami ważną rolę odgrywają podobieństwa celów, interesów czy wspólnych wartości, np. pobożność, poszanowanie dla wolności jednostki, w myśl zasady similis simili gaudet - podobny z podobnym jest zadowolony (Plusnin, 1993).

Zjawisko przyjaźni pozostaje interesujące i otwarte dla dalszych badań. Uwzględnienie nie tylko różnic międzypłciowych, lecz także wiekowych, różnic między przyjaźnią wirtualną a realną oraz prowadzenie badań w różnych kontekstach kulturowych pozwoli na dokładniejsze poznanie tej ważnej, aczkolwiek wciąż stosunkowo słabo zbadanej sfery ludzkiego życia w perspektywie porównawczej np. między Ukrainą a innymi krajami Europy Środkowo-Wschodniej. Badania te pozwoliłyby uchwycić różnice kulturowe (np. w odniesieniu do wymiarów kulturowych Hofstede), które istnieją mimo zbliżonego położenia geogograficznego, oraz wielu podobieństw w językach tych krajów.

\section{Podzięrowania}

Dziękuję dwóm anonimowym recenzentom, których komentarze miały bardzo pozytywny wpływ na końcową postać artykułu. Wszelkie błędy i niedopatrzenia w niniejszym artykule wynikają wyłącznie $\mathrm{z}$ winy autora.

\section{Bibliogr AFi A}

Adams, G., Plaut, V. C. (2003). The cultural grounding of personal relationship: Friendship in North American and West African worlds. Personal Relationships, 10(3), 333-347.

Altman, I., Taylor, D. (1973). Social Penetration: The Development of Interpersonal Relationships. Nowy Jork: Holt, Rinehart and Winston.

Amichai-Hamburger, Y., Kingsbury, M., Schneider, B. H. (2013). Friendship: An old concept with a new meaning. Computers in Human Behavior, 29(1), 33-39. Andersen, S. M., Chen, S. (2002). The relational self: An interpersonal social-cognitive theory. Psychological Review, 109(4), 619-645.

Andrzejuk, I. (2009). Przyjaźń w ujęciu Arystotelesa i Tomasza z Akwinu jako przykład teologicznego poszerzenia problematyki filozoficznej. Studia Leopoliensia, 2, 81-88.

Andrzejuk, I. (2011). Rola przyjaźni w wychowaniu człowieka. Studia Philosophiae Christianae, 47(2), 231-241.

Arystoteles (2007). Etyka nikomachejska. Warszawa: PWN.

Ball, B., Newman, M. E. (2013). Friendship networks and social status. Network Science, 1(01), 16-30. 
Baltzly, D., Eliopoulos, N. (2009). The Classical Ideals of Friendship. W: B. Caine (red.), Friendship: A History (s. 12-68). Sheffield: Equinox.

Banaji, M. R., Prentice, D. A. (1994). The self in social contexts. Annual Review of Psychology, 45, 297-332.

Blau, P. M. (1964). Exchange and power in social life. Nowy Jork: John Wiley. Bohonkova, Û. (2014). Vìkovì ta psihologičnì osoblivostì mižosobistìsnogo spilkuvannâ ûnakìv. Zbirnik naukovih prac': psihologîa, 19(1), 20-25.

Brzezińska, A. (2005). Współzależność kontekstu rozwoju, stylu życia i struktury Ja. W: J. Kmita, I. Kotowa, J. Sojka (red.), Nauka. Humanistyka. Człowiek (s. 57-74). Poznań: Wydawnictwo Naukowe UAM.

Burns, R. B. (1982). Self-Concept Development and Education. University of Michigan Press.

Byrne, D. (1961). Interpersonal attraction and attitude similarity. The Journal of Abnormal and Social Psychology, 62(3), 713-715.

Campbell, J., Assanand, S., Di Paula, A. (2004). Cechy strukturalne pojęcia Ja a przystosowanie. W: A. Tesser, R. Felson, J. Suls (red.), Ja i tożsamość (s. 70-88). Gdańsk: GWP.

Cooper, J. (1980). Aristotle on Friendship. W: A. O. Rorty (red.), Essays on Aristotle's Ethics (s. 301-340). Berkeley: University of California Press.

Darley, J. M., Berscheid, E. (1967). Increased linking as a result of the anticiration of personal contact. Human Relations, 20(1), 29-40.

Dijkstra, J. K., Cillessen, A. H., Borch, C. (2013). Popularity and adolescent friendship networks: Selection and influence dynamics. Developmental Psychology, 49(7), 12-42.

Dryer, D. C., Horowitz, L. M. (1997). When Do Opposites Attract? Interpersonal Complementarity Versus Similarity. Journal of Personality and Social Psychology, 72(3), 592-603.

Feingold, A. (1988). Matching for attractiveness in romantic partners and same-sex friends: A meta-analysis and theoretical critique. Psychological Bulletin, 104(2), 226-235.

Fetiskin, N. P., Kozlov, V. V., Manujlov, G. M. (2002). Social'no-psihologičeckaâ diagnostika razvitiâ ličnosti i malyh grupp. Państwowy Uniwersytet w Moskwie.

Grabińska, T. (2010). Miłość a przyjaźń w etyce Arystotelesa. Fides et ratio, 3(3), $18-24$.

Gutowska, A. (2011). Przyjaźń a zdrowie psychiczne w okresie starości. W: A. Fabias, M. Muszyński (red.), Społeczne wymiary starzenia się (s. 157-172). Bielsko-Biała: Agencja Wydawniczo-Reklamowa Omnidium.

Hall, C. S., Lindzey, G. (1994). Teorie osobowości. Warszawa: PWN.

Hensley, W. E. (1994). Height as a basis for interpersonal attraction. Adolescence, 29, 469-474. 
Higgins, E. T., Bargh, J. A. (1987). Social Cognition and Social Perception. Annual Review of Psychology, 38, 369-425.

Hofstede, G. (2011). Dimensionalizing cultures: The Hofstede model in context. Online readings in psychology and culture, 2(1), 8.

Hofstede, G., Hofstede, G. J. (2007). Kultury i organizacje. Polskie Wydawnictwo Ekonomiczne.

Hofstede, G. J., Minkov, M., Hofstede, G. (2016). Allemaal andersdenkenden: omgaan met cultuurverschillen. Amsterdam: Business Contact.

Homans, G. C. (1961). Social behavior: Its elementary forms. Nowy Jork: Harcourt Brace.

Ilmarinen, V. J., Lönnqvist, J. E., Paunonen, S. (2016). Similarity-attraction effects in friendship formation: Honest platoon-mates prefer each other but dishonest do not. Personality and Individual Differences, 92, 153-158.

Jakubowski, J. (1970). Zarys teorii osobowości Karola R. Rogersa. Studia Philosophiae Christianae, 6(1), 68-91.

Juroszek, W. (2014). Relacje małżonków z matką i teściową w świetle teorii niezależności/współzależności Ja. Kwartalnik Naukowy Fides et Ratio, 18, 64-73.

Klohnen, E. C., Luo, S. (2003). Interpersonal attraction and personality: What is attractive - self similarity, ideal similarity, complementarity or attachment security? Journal of Personality and Social Psychology, 85(4), 709-722.

Klimenko, Ê. O. (2010). Družba âk rìznovid atrakciì. Viisnik Černigivskogo Nacional'nogo Pedagogičnogo Universitetu, 1(82), 225-227.

Kon, I. S. (1980). Friendship in adolescence: Values and behavior. Journal of Marriage and the Family, 40(1), 143-155.

Kon, I. S. (2005). Družba. Sankt-Petersburg: Piter.

Konstan, D. (1997). Friendship in the classical world. Londyn: Cambridge University Press.

Kristof-Brown, A., Barrick, M. R., Stevens, C. K. (2005). When Opposites Attract: A Multi-Sample Demonstration of Complementary Person-Team Fit on Extraversion. Journal of personality, 73(4), 935-957. DOI:10.1111/j.1467-6494.2005.00334.x

Kubicka, E., Suwała, M. (2013). Słownik łacińsko-polski, polsko-łaciński. Toruń: Literat.

Kulagina, I. U.., Kolûckij, V. N. (2001). Vozrastnaâ psihologiâ: Polnyj žiznennyj cikl razvitiâ čeloveka. Moskwa: Ûrajt.

Kunst-Wilson, W. R., Zajonc, R. B. (1980). Affective discrimination of stimuli that cannot be recognized. Science, 207, 557-558.

Maaß, U., Lämmle, L., Bensch, D., Ziegler, M. (2016). Narcissists of a Feather Flock Together: Narcissism and the Similarity of Friends. Personality and Social Psychology Bulletin, 42(3), 366-384.

McCroskey, J. C., McCain, T. A. (1974). The measurement of interpersonal attraction. Speech Monographs, 41(3), 261-266. 
McGinnis, A. L. (1991). Sztuka przyjaźni. Warszawa: Vocatio.

Moreland, R. L., Zajonc, R. B. (1977). Is stimulus recognition a necessary condition for the occurrence of exposure effects? Journal of Personality and Social Psychology, 35(4), 191-199.

Morry, M. M. (2007). The attraction-similarity hypothesis among cross-sex friends: Relationship satisfaction, perceived similarities, and self-serving perceptions. Journal of Social and Personal Relationships, 24(1), 117-138.

Murray, H. A. (1938). Explorations in personality. Oxford University Press.

Murstein, B. I., Azar, J. A. (1986). The relationship of exchange-orientation to friendship intensity, roommate compatibility, anxiety, and friendship. Small Group Research, 17(1), 3-17.

Newcomb, T. M. (1956). The prediction of interpersonal attraction. American Psychologist, 11, 575-586.

Obrębska, M., Paniotova, D. Językowy obraz przyjaźni studentów polskich i ukraińskich. Czasopismo Psychologiczne. Artykuł w przygotowaniu.

Osgood, C. E., Suci, G., Tannenbaum, P. (1957). The Measurement of Meaning. University of Illinois Press.

Padilla-Walker, L. M., Fraser, A. M., Black, B. B., Bean, R. A. (2015). Associations between friendship, sympathy, and prosocial behavior toward friends. Journal of Research on Adolescence, 25(1), 28-35.

Palombo, J., Koch, B. J., Bendicsen, H. K. (2009). Guide to Psychoanalytic Developmental Theories. Nowy Jork: Springer.

Plûsnin, Û. M. (1993). Kakih druzej my sebe vybiraem? Sociobiologiâ drużby. Priroda, 9, 75-83.

Reilly, M. St. A., Commins, W. D., Stefic, E. C. (1960). The complementarity of personality needs in friendship choice. The Journal of Abnormal and Social Psychology, 61(2), 292-294.

Rodina, A.M.(2000). Predstavlenie o družbe io cebe vrazličnye periodyžizni čeloveka [Reprezentacja siebiei przyjaciela w różnych okresach życia człowieka] (rozprawa doktorska, Sankt Petersburg). Pobrane z: http://www.dissercat.com/content/ predstavlenie-o-druzhbe-i-o-sebe-v-razlichnye-periody-zhizni-cheloveka

Rogers, C. R. (1951). Client-centered therapy. Nowy Jork: Houghton Mifflin.

Rogers, C. R. (1959). A theory of therapy, personality and interpersonal relationships, as developed in the client-centered framework. W: S. Koch (red.), Psychology: A study of science (s. 184-256). Nowy Jork: McGraw Hill.

Rogers, C. R. (1961). On Becoming a person: A psychotherapists view of psychotherapy. Houghton Mifflin.

Rogers, C. R. (1965). A humanistic conception of man. W: R. E. Farson (red.), Science and human affairs. Kalifornia: Science and Behavior Books.

Rogers, C. R. (1977). Carl Rogers on personal power. Nowy Jork: Delacorte Press. Schug, J., Yuki, M., Horikawa, H., Takemura, K. (2009). Similarity attraction and actually selecting similar others: How cross-societal differences in relational 
mobility affect interpersonal similarity in Japan and the USA. Asian Journal of Social Psychology, 12(2), 95-103. DOI:10.1111/j.1467-839X.2009.01277.x

Sciangula, A., Morry, M. M. (2009). Self-Esteem and Perceived Regard: How I See Myself Affects My Relationship Satisfaction. The Journal of Social Psychology, 149(2), 143-158.

Selfhout, M. H., Branje, S. J., Meeus, W. H. (2007). Similarity in adolescent best friendships: The role of gender. Netherlands Journal of Psychology, 63(2), $42-48$.

Serdûk, N. I. (2015). Vpliv psihologičnih umov formuvannâ atrakciï na mižosobistisni stosunki pidlitkiv. Young Scientist, 2(17), 431-434.

Stafford, L. (2015). Social Exchange Theories: Calculating the Rewards and Costs of Personal Relationships. W: D. O. Braithwaite, P. Schrodt (red.), Engaging Theories in Interpersonal Communication: Multiple Perspectives (s. 403-417). SAGE.

Suszek, H. (2007). Różnorodność wielości Ja. Roczniki Psychologiczne, 10(2), 7-37. Szarota, P. (2014). Przyjaźń pod mikroskopem. Problemy metodologiczne w badaniach nad funkcjonowaniem relacji przyjacielskich. Psychologia Społeczna, 9, 28-36. DOI:10.7366/189618002014280102

Sztompka, P., Boguni-Borowska, M. (2008). Socjologia codzienności. Kraków: Znak.

Thibaut, J. W., Kelley, H. H. (1959). The social psychology of groups. Nowy Jork: John Wiley.

Vasilevs'kij, Ê. (2010). Psihologì̌nì faktori atrakciï v mì̌osobistìsnih stosunkah. Visnik students'kogo naukovogo tovaristva deržavnogo universitetu im. Mikoli Gogolâ v Nižini, 6(1), 60-66

White, G. L. (1980). Physical Attractiveness and Courtship Progress. Journal of Personality and Social Psychology, 39, 660-668.

Wierzbicka, A. (2007). Słowa klucze. Różne języki - różne kultury. Wydawnictwo Uniwersytetu Warszawskiego.

Winch, R. F., Ktsanes, T., Ktsanes, V. (1955). Empirical elaboration of the theory of complementary needs in mate-selection. The Journal of Abnormal and Social Psychology, 51(3), 508-513.

Winstead, B. A., Derlega, V. J. (1986). Friendship and Social Interaction. Nowy Jork: Springer-Verlag.

Zajonc, R. B. (1980). Feeling and thinking: Preferences need no inferences. American psychologist, 35(2), 151-175.

Zeggelink, E. (1995). Evolving friendship networks: An individual-oriented approach implementing similarity. Social Networks, 17, 83-110.

Znaniecki, F. (1965). Social Relations and Social Roles: The Unfinished Systematic Sociology. USA: Chandler Publishing Company. 